\title{
A Laboratory Investigation for Shear Modulus of Silty Sand Soils
}

\author{
Mehmet Inanc Onur \\ Department of Civil Engineering, Anadolu University \\ Eskisehir, Turkey \\ mionur@anadolu.edu.tr
}

\begin{abstract}
Dynamic shear modulus gives information about dynamic soil response and deformability characteristics. Dynamic shear modulus of the soils can be determined by using field tests or laboratory experiments such as resonant column method. In this study, a series of resonant column test were performed on reconstituted silty sand samples. Silty sand samples were collected from the city of Eskisehir, Turkey. Silty sand samples were prepared at different relative densities, confining pressures and saturation degrees. Results of the tests showed that the shear modulus changes with relative density, confining pressure and saturation degree.
\end{abstract}

Keywords: shear modulus, silty sand, resonant column test

\section{Introduction}

Dynamic shear modulus gives information about dynamic soil response and deformability characteristics. Dynamic shear modulus is defined as the ratio of the shear stress to the shear strain in the literature. Shear modulus is shown with the abbreviation "G" but initial shear modulus "Go" and maximum shear modulus "Gmax" are used frequently. Dynamic shear modulus of the soils can be measured by using field tests or laboratory experiments. Shear modulus is calculated from the shear wave velocity and density of the soil. On the other hand, shear modulus can be calculated by using the equations that involve void ratio and mean effective principle stress. Typical values of the initial shear modulus for different types of soils are given in Table 1 .

Table 1: Typical values of $\mathrm{G}_{0}$ (AASHTO, 1996).

\begin{tabular}{|c|c|}
\hline Soil Type & Shear Modulus, $\mathrm{G}_{\mathrm{o}}(\mathrm{kPa})$ \\
\hline Dense Sands \& Gravels & $69000-345000$ \\
\hline Silty Sand & $27600-138000$ \\
\hline Medium Stiff Clay & $6900-34500$ \\
\hline Soft Clays & $2750-13750$ \\
\hline
\end{tabular}

Resonant column method is used to determine dynamic shear modulus of the soils in the laboratory. This method is preferred widely due to the advantages such as simplicity and rapidity. In the test, soils are subjected to torsional loading with different frequencies. Wave velocities, damping ratios and shear modulus of the soil samples can be easily determined by using derivation of the function of the motion.

Youn et al. [1] determined the shear modulus of dry and saturated sands by performing bender element, resonant column and torsional shear tests. Tatsuoka et al. [2] investigated the effects of sample preparing methods on the dynamic shear modulus by using resonant column test. Wang and Kuwano [3] modelled the dynamic shear modulus behavior of sand-clay mixtures. Markowska-lech [4] studied the stress effect on the shear modulus of cohesive soils. Cascante et al. [5] presented a new method to determine the shear modulus of soils by modification the resonant column test. 
Builes et al. [6] analysed the shear modulus changes under dynamic loading. Khan et al. [7] improved a new methodology to comparison of dynamic shear modulus and soil strength against the dynamic loading by using bender element test. Kokusho [8] compared the resonant column test and dynamic triaxial test for determining shear modulus of the soils. Altun and Ansal [9] found the dynamic shear modulus of sandy mixtures. Sener et al. [10] investigated the relationship between shear modulus and shear strain at different axial deformation levels.

Some soil state factors have effect on the dynamic shear modulus of the soils. Especially, void ratio and confining pressure have great effect on the shear modulus. However, degree of saturation can affect the damping and dynamic shear modulus [11]. In this study, shear modulus of silty sand samples were determined at different relative densities with confining pressures and saturation degrees. Results and conclusions were given.

\section{Experimental Study}

All test steps were performed according to the ASTM D4015-07. It is reported that resonant column test results are independent from the methods of sample preparation [2]. And also results are not much affected above $100 \mathrm{kPa}$ confining pressure from laboratory factors [12]. Non-plastic and fine- grained silty sand soil samples were used for the experiments. Silty sand samples were collected from the city of Eskisehir, Turkey. Basic characteristics are given in Table 2. The reconstituted soil samples have $70 \mathrm{~mm}$ in diameter and $145 \mathrm{~mm}$ in length, respectively.

Table 2: Basic characteristics of silty sand soil.

\begin{tabular}{|c|c|}
\hline USCS & SW-SM \\
\hline Coefficient of Uniformity, $\mathrm{Cu}$ & 14,66 \\
\hline Coefficient of Curvature, Cc & 2,45 \\
\hline Amount of Gravel & $24 \%$ \\
\hline Amount of Sand & $66 \%$ \\
\hline Amount of Silt-Clay & $10 \%$ \\
\hline Natural Unit Weight & $17,8 \mathrm{kN} / \mathrm{m} 3$ \\
\hline Plasticity & Non-Plastic \\
\hline
\end{tabular}

Tests were performed by using resonant column test and the device is given in Figure 1. The system is using fixedfree configuration and a cylindrical soil specimen is excited in torsion. Firstly, resonant frequency is determined and then wave velocity can be measured. After the measurement of shear wave velocity, shear modulus of the samples are calculated by using sample density.

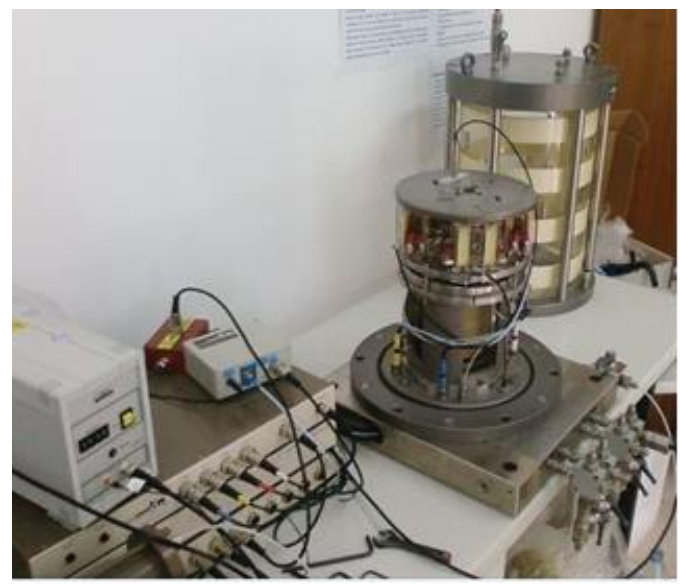

Fig. 1: GDS resonant column test device. 
Resonant column tests were performed by applying different cell pressures at different saturation degrees and different relative densities. Saturation and consolidation test steps were performed by following standard techniques. All tests were performed after reaching 0.95 Skempton B value for fully saturated tests. Moist placement method was chosen for the partially saturated tests as well. Consolidation tests werre performed after saturation. Then, resonant frequencies were measured and values of shear modulus were calculated. Cell pressures were applied as 100 and $200 \mathrm{kPa}$ and saturation degrees were chosen as $40 \%$ and $100 \%$. Relative densities werere calculated from initial void ratios and found as 40,60 and $80 \%$. All test parameters such as pressure, saturation and relative density are given in Table 3 .

Table 3: Test Details.

\begin{tabular}{|c|c|c|c|}
\hline Test No & $\begin{array}{c}\text { Relative } \\
\text { Densities } \\
(\%)\end{array}$ & $\begin{array}{c}\text { Saturation } \\
\text { Degrees } \\
(\%)\end{array}$ & $\begin{array}{c}\text { Confining } \\
\text { Pressures } \\
(\mathrm{kPa})\end{array}$ \\
\hline Test A & 40 & 40 & $100-200$ \\
\hline Test B & 40 & 10 & $100-200$ \\
\hline Test C & 60 & 40 & $100-200$ \\
\hline Test D & 60 & 0 & 10 \\
\hline Test E & 80 & $400-200$ \\
\hline Test F & 80 & 0 & $100-200$ \\
\hline & & 0 & $100-200$ \\
\hline
\end{tabular}

\section{Results}

While performing resonant column tests, shear wave velocities were found between $170 \mathrm{~m} / \mathrm{s}$ and $260 \mathrm{~m} / \mathrm{s}$. Therefore, shear modulus of the samples were calculated between $51 \mathrm{MPa}$ and $130 \mathrm{MPa}$. The calculated shear modulus values were given in Table 4. It can be seen from the results that test results of the experimental study show similar behaviour with the results of the literature. Especially, relative density has great effect on the shear modulus of the samples. Shear modulus of the samples is affected from the saturation but the differences are in small proportions. And also, the shear modulus of the samples is increasing with the increase of confining pressure. The maximum shear modulus values are measured at less saturation degree, higher relative density and confining pressures. Because soil particles are getting closer to each other, therefore the shear modulus increases. 
Table 4: Test results.

\begin{tabular}{|l|c|c|}
\hline Test Number & $\begin{array}{c}\text { Confining } \\
\text { Pressures } \\
(\mathbf{k P a})\end{array}$ & $\begin{array}{c}\text { Shear Modulus } \\
\text { (MPa) }\end{array}$ \\
\hline Test A & 100 & 54,71 \\
\hline Test A & 200 & 69,14 \\
\hline Test B & 100 & 51,26 \\
\hline Test B & 200 & 65,60 \\
\hline Test C & 100 & 77,54 \\
\hline Test C & 200 & 102,65 \\
\hline Test D & 100 & 70,20 \\
\hline Test D & 200 & 96,42 \\
\hline Test E & 100 & 85,27 \\
\hline Test E & 200 & 132,15 \\
\hline Test F & 100 & 83,33 \\
\hline Test F & 200 & 130,94 \\
\hline
\end{tabular}

\section{Conclusion}

In this study, the results of an experimental laboratory investigation were presented. Tests were performed by using resonant column test device. The shear modulus of silty sand samples was determined in laboratory. Silty sand samples were prepared at different relative densities, confining pressures and saturation degrees. The results of the tests showed that relative densities, confining pressures and saturation degrees have different influence values on the shear modulus of the silty sand soils. On the other hand, for the further works and field tests should be done to simulate site conditions, besides laboratory tests.

\section{Acknowledgements}

This study was supported by Anadolu University Scientific Research Projects Commission under the grant no: 1603F117. Special thanks to Anadolu University Scientific Research Project Presidency.

\section{References}

[1] J. Youn, Y. W. Choo, D. S. Kim, "Measurement of small-strain shear modulus $\mathrm{G}_{\max }$ of dry and saturated sands by bender element, resonant column and torsional shear tests," Can. Geotech. Journal, vol. 45, pp. 1426-1438, 2008.

[2] F. Tatsuoka, T. Iwasaki, S. Yoshida, S. Fukushima, H. Sudo, "Shear modulus and damping by drained tests on clean sand specimens reconstituted by various methods," Soils and Foundations, vol. 19, no. 1, pp. 39-54, 1979.

[3] G. X. Wang, J. Kuwano, "Modelling of strain dependency of shear modulus and damping of clayey sand," Soil Dynamics and Earthquake Engineering, vol. 18, pp. 463-471, 1999. 
[4] K. Markowska-Lech, "The determination of shear modulus in overconsolidated cohesive soils," Foundations of Civil and Environmental Engineering, vol. 12, pp. 61-71, 2008.

[5] G. Cascante, C. Santamarina, N. Yassir, "Flexural excitation in a standard torsional-resonant column device," Can. Geotech. Journal, vol. 35, pp. 478-490, 1998

[6] M. Builes, E. Garcia, C. A. Riveros, "Dynamic and static measurements of small strain moduli of Toyoura sand," Rev. Fac. Ing. Univ. Antioquia, vol. 43, pp. 86-101, 2008.

[7] A. Khan, M. H. El Naggar, G. Cascante, "Frequency dependent dynamic properties from resonant column and cyclic triaxial tests," Journal of the Franklin Institute, vol. 348, pp. 1363-1376, 2011.

[8] T. Kokusho, "Cyclic triaxial test of dynamic soil properties for wide strain range," Soils and Foundations, vol. 20, no. 2, pp. 305-312, 1980.

[9] S. Altun, A. Ansal, "Determination of the shear modulus of sand soils," in Proc. of the XVII. Technical Congress, Istanbul, pp. 403-406, 2004.

[10] A. Sener, M. Özmen, Z. Kaya, A. Erken, "The behavior of soils in dynamic triaxial and torsional shear test systems," in Proc. of the 2. Geotechnical Symposium, Adana, pp. 359-371, 2007.

[11] M. İ. Onur, M. Tuncan, A. Tuncan, "An Experimental study for determining the shear modulus of Toyoura sand," in Proc. of Second European Conference on Earthquake Engineering and Seismology, İstanbul, Poster No: 829, 2014.

[12] M. İ. Onur, M. Tuncan, A. Tuncan, "Factors Affecting the Dynamic Shear Modulus Behaviour of Toyoura Sand," in Proc. of 4th International Conference on New Developments in Soil Mechanics and Geotechnical Engineering, Nicosia, pp. 751-756, 2016. 